\title{
Utilization Of Cork Cocopeat As A Composite Silencer
}

\author{
S. Djiwo ${ }^{1}$, T. Sugiarto ${ }^{1}$, E. Y. Setyawan ${ }^{1}$ \\ ${ }^{1}$ Department of Mechanical Engineering, National Institute of Technology, Malang, Indonesia \\ Email: Soeparno_D@fti.itn.ac.id
}

\begin{abstract}
Noise is unwanted sound of activity in a particular time and levels that can cause health problems and environmental comfort. Therefore, to minimize noise with materials that are biodegradable with composite materials. One effort in selecting materials that are biodegradable with coconut plant utilization have been known by the wider community wastes a lot of cocopeat i.e. we encounter in a craftsmen coir because its existence is underutilized by craftsmen. Methods used i.e. experimental methods, with chemical treatment of cocopeat aims to separate dirt and the lignin contained in the cocopeat so cocopeat can bind matrix that would have a high performance in the muffle the sound so that it can reduce noise. After treatment with alkali, creating a noise test specimens in accordance with the design of the mold. The results showed, the percentage composition of the powder of coconut fibres (cocopeat) have an influence in absorbing sound. In this study the composition of the powder of coconut fibres (cocopeat) $60 \%$ has a high sound absorbency. Desible votes after going through the composite powder coconut fibres $60 \%$ has a value of $102.73 \mathrm{db}$ at a distance of $50 \mathrm{~cm}, 100 \mathrm{db}$ at a distance of $91.57 \mathrm{~cm}$ and $80.23 \mathrm{db}$ at a distance of $150 \mathrm{~cm}$. And sound absorbency coefficient on the composition of the powder of coconut fibres $60 \%$ has a value of 0.144 on a distance of $50 \mathrm{~cm}, 100 \mathrm{~cm}$ at a distance of 0.237 and 0.331 approximately $150 \mathrm{~cm}$. Whereas in terms of surface morphology of SEM photo of that on the composition of the powder $60 \%$ coconut fibers have more porosity percentage which has absorption ability voice more effectively so that the sound after passing the composition of composite lower.
\end{abstract}

Keywords noise, Biodegradable Composite, cocopeat, SEM.

Paper type Research paper

\section{INTRODUCTION}

Noise noise caused by giving rise to a vibrating source. Source vibrations sound disturbing the air molecules around until the molecules by vibrating. This causes the occurrence of vibration source of wave energy-rambatan 3rd mechanised in the medium conditioning according to pattern rambatan longitudional. The voice is not intended will give bad effects to the health of. Voice is a mechanical waves transmitted by a medium yaitu generally by air. However, and quantity voice determined inter alia by intensitas (loudness), frequency, periodesitas (kontinyu or disconnected) and durasinya. The factors affecting the impact a follow on the health of the noise. Noise can be disruptive at indera hearing acoustic trauma, as well as other deaf temporary, until ketulian permanen.

To minimise noise caused from sound source by using ingredients silencers. One of the physical properties of the material can be owned mute that is, has a small pore pore - so that the value of density is high, have characteristics such as its elasticity value of rubber that can withstand high vibration and has power high absorbency.

Composite materials expected to be used for the subject of silencers, certainly as a solution to prove that the composite material able to muffle the sound of noise. The composite materials has been one of alternative materials used household appliances, medical equipment, pharmacy equipment, and transportation, as well as military equipment and airplanes. This is because the composite has a great sound, and vibration which is better when compared to metallic materials[1].

Cocopeat is waste from coir fibres capture the yet underutilized. In Indonesia an annual average of coconut fruit can be generated as much as 15.5 billion grains. From those results can be produced 1.8 million tons of wire, and 3.3 million tons of cocopeat according [2][3][4][5]. The availability of raw materials, cocopeat coconut fibers should be utilized to produce various products worth economic and environmentally friendly. The Cocopeat have started planting media utilized as by farmers, but still not a lot of it anyway. On this research functions as cocopeat dampen noise[6][7].

Issue that evolves today about environmental issues has encouraged researchers to find new materials that have the nature and behavior of eco-friendly, bio-degradable, bio-composites, bio-materials, bio-fuels and green environment. Those terms appear in line with the UN Declaration that the year 2009 was the year the International Years of Natural Fibers (IYNF) agreed in December 2006 [8]. The program will be facilitated by the UN FAO (Food and Agricultural Organization) for the welfare of society is the sustainable future. 
Problems encountered was finding ingredients that come from nature and have the capability of degradation of naturally and very abundant availability of resources or able to be updated. This assertion encourages researchers to uncover kamampuan cocopeat to absorb noise. The benefits to be gained is as a guide for users of composite materials in particular. In a research note this very noise because the minimum sound pressure level that is capable of evoking an auditory sensation in ear receiver called the brink ability be heard (threshold of hearing). The minimum sound pressure levels that stimulate the ears to a situation where any discomfort caused particular pain referred pain threshold (threshold of pain). Because the threshold of the ability to be heard and the threshold of pain that limits the area of auditory sensation and can cause damage to the ear.

\section{MeTHOD}

\section{Materials}

Coconut powder (cocopeat) obtained after the serabutnya separated. Cocopeat coir which is processed into grain-grain Cork, known also by the name of Cocopeat. Using the matrix. Polyester resins have a low price, easy to use and the nature of the versalitasnya. In addition it has polyester durability against impact, resistant to all weather, transparent and good surface effect. The loss of the use of polyester resin is having a less good adhesive strength and nature of the inhibition of aerial and filler.

\section{Manufacture Composite}

Raw materials undergo an initial treatment of cocopeat, washed with lye i.e. $5 \% \mathrm{NaOH}$ and washed with water aquades to the level of acidity $(\mathrm{pH})$ showing number 7. The powder is dried and dried diruangan open followed by oven drying according to the standard ASTM D629 Qualitative Analysis of Textile Materials to obtain the moisture regain and moisture content [9][10][11]. The results of early treatment of cocopeat on later stage prepared for composite manufacturing process in accordance with the specimen.

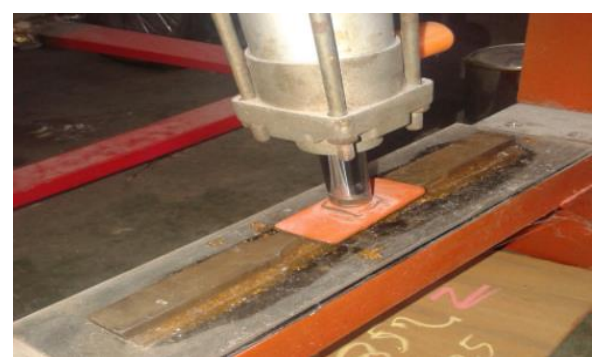

Figure 1. Composite suppressor.

The process of pembutan composite with the process of hand lay up used hydraulic emphasis with pressure 150 Psi for 2 hours, with the help of the air from the compressor with the air temperature outside of the approximately $280 \mathrm{c}$. each number of specimens made 3 pieces.
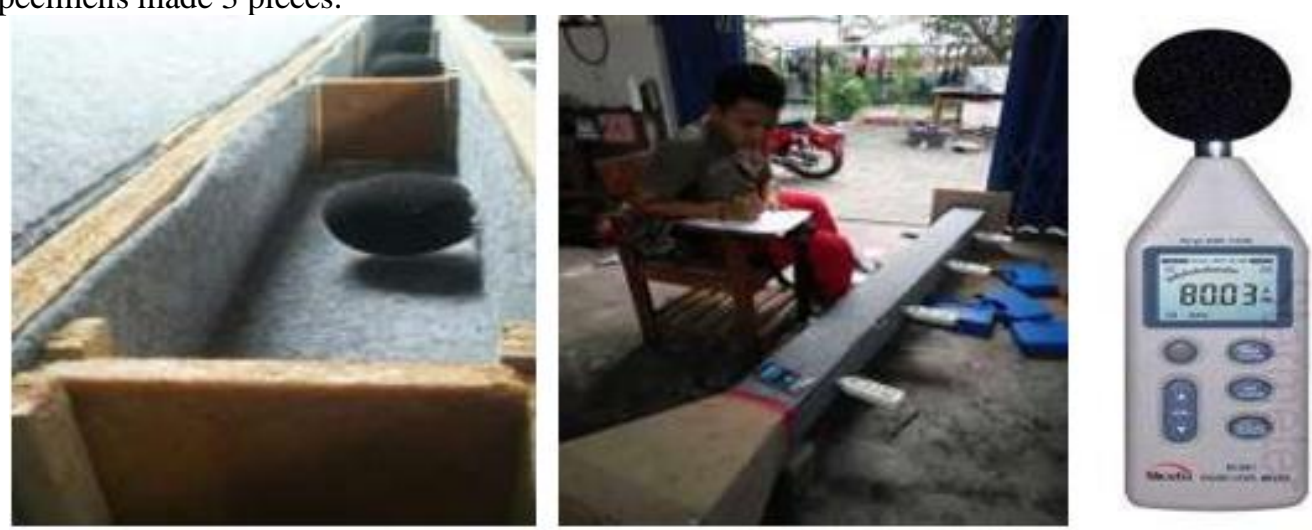

Figure 2. Tool noise test

\section{Macro Photo Observations}

conducted to figure out the difference of surface condition specimen due to faulting and the manufacturing process using the method of hand lay up, photos of SEM was used to analyze the morphology of composite powder with coconut polyester matrix after testing is done to see the fault. 


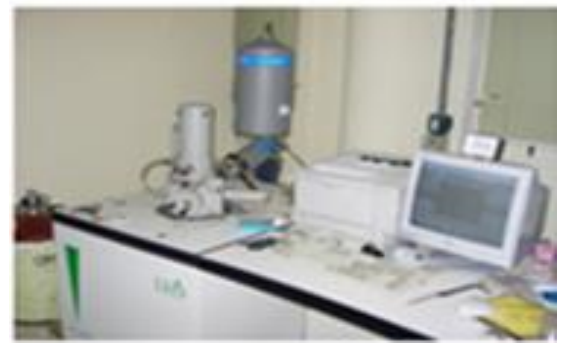

Figure 3. SEM

\section{DISCUSSION}

In this study, the materials used in the manufacture of composite specimens i.e., waste from the production of coconut fibres (Cocopeat) mixed with polyester matrix using the method of hand lay-up. In using this method worked on a simple, easy and not much cost. But on the other hand, this method also has drawbacks because it is all done manually, not yet fully scalable so it requires special skills in composite spesiment pembutan. For example in Figure 4.

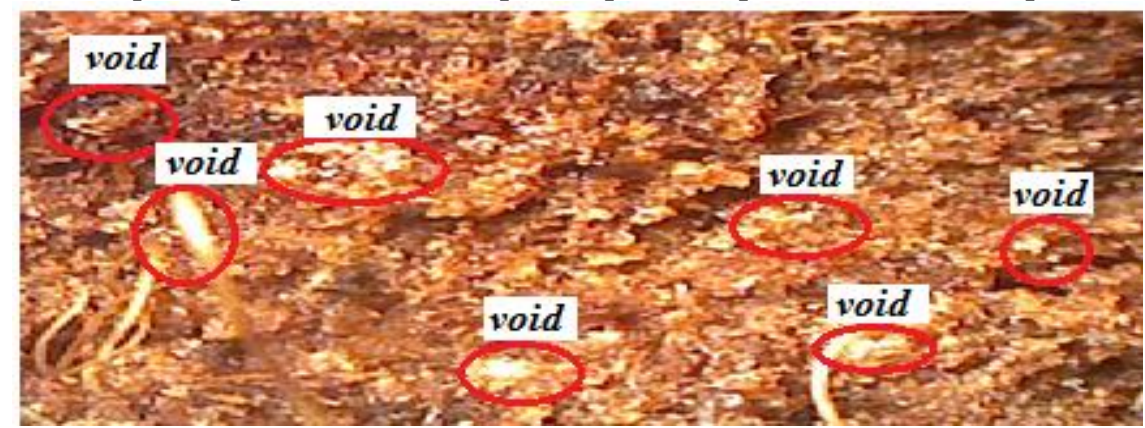

Figure 4 macro Photo composite powder coconut fibres with a matrix of polyester

In the process of making specimen of difficulty is not resolved, remove air trapped in composite and composite surfaces that cannot be flattened, turned out to be a method of hand lay-up wasn't enough to handle the problem as shown in Figure 4 where the visible voids and uneven surfaces. On the other hand powder coconut fibres included in hydrophilic regime capable of absorbing water or moist air so that there is a void in the composite that could affect the strength in absorbing sound, owned by composite.

A. Noise Test

Table 1 Test Data measurement noise

\begin{tabular}{ccccccc}
\hline & \multicolumn{6}{c}{ Jarak Spesimen Terhadap Sumber Bunyi } \\
\cline { 2 - 7 } Spesimen & $\begin{array}{c}\text { Energi } \\
\text { Sumber } \\
\text { Suara } \\
\end{array}$ & $\begin{array}{c}\text { Energi } \\
\text { Serap }\end{array}$ & $\begin{array}{c}\text { Energi } \\
\text { Sumber } \\
\text { Suara }\end{array}$ & $\begin{array}{c}\text { Energi } \\
\text { Serap }\end{array}$ & $\begin{array}{c}\text { Energi } \\
\text { Sumber } \\
\text { Suara }\end{array}$ & $\begin{array}{c}\text { Energi } \\
\text { Serap }\end{array}$ \\
& 120 & $(\mathrm{db})$ & $(\mathrm{db})$ & $(\mathrm{db})$ & $(\mathrm{db})$ & $(\mathrm{db})$ \\
\hline $40 \%-60 \%$ (a) & 1204,5 & 120 & 93 & 120 & 82,8 \\
$40 \%-60 \%$ (b) & 120 & 105 & 120 & 93,3 & 120 & 82,9 \\
$40 \%-60 \%$ (c) & 120 & 104,8 & 120 & 93,4 & 120 & 82,6 \\
\hline Rata-rata & $\mathbf{1 2 0}$ & $\mathbf{1 0 4 , 7 7}$ & $\mathbf{1 2 0}$ & $\mathbf{9 3 , 2 3}$ & $\mathbf{1 2 0}$ & $\mathbf{8 2 , 7 7}$ \\
\hline $50 \%-50 \%$ (a) & 120 & 103,7 & 120 & 92,5 & 120 & 81,1 \\
$50 \%-50 \%$ (b) & 120 & 103,4 & 120 & 92 & 120 & 81,5 \\
$50 \%-50 \%$ (c) & 120 & 103,3 & 120 & 92,7 & 120 & 81,4 \\
\hline Rata - rata & $\mathbf{1 2 0}$ & $\mathbf{1 0 3 , 4 7}$ & $\mathbf{1 2 0}$ & $\mathbf{9 2 , 4}$ & $\mathbf{1 2 0}$ & $\mathbf{8 1 , 3 3}$ \\
\hline $60 \%-40 \%$ (a) & 120 & 102,9 & 120 & 91,8 & 120 & 80,3 \\
$60 \%-40 \%$ (b) & 120 & 102,7 & 120 & 91,6 & 120 & 80 \\
$60 \%-40 \%$ (c) & 120 & 102,6 & 120 & 91,3 & 120 & 80,4 \\
\hline Rata - rata & $\mathbf{1 2 0}$ & $\mathbf{1 0 2 , 7 3}$ & $\mathbf{1 2 0}$ & $\mathbf{9 1 , 5 7}$ & $\mathbf{1 2 0}$ & $\mathbf{8 0 , 2 3}$ \\
\hline
\end{tabular}

From table 1 data the test results with the variation of mass with any variation of the test specimen 3 to get valid data. From these data so obtained the charts to know the State of any changes to such a test in Figure 5. 


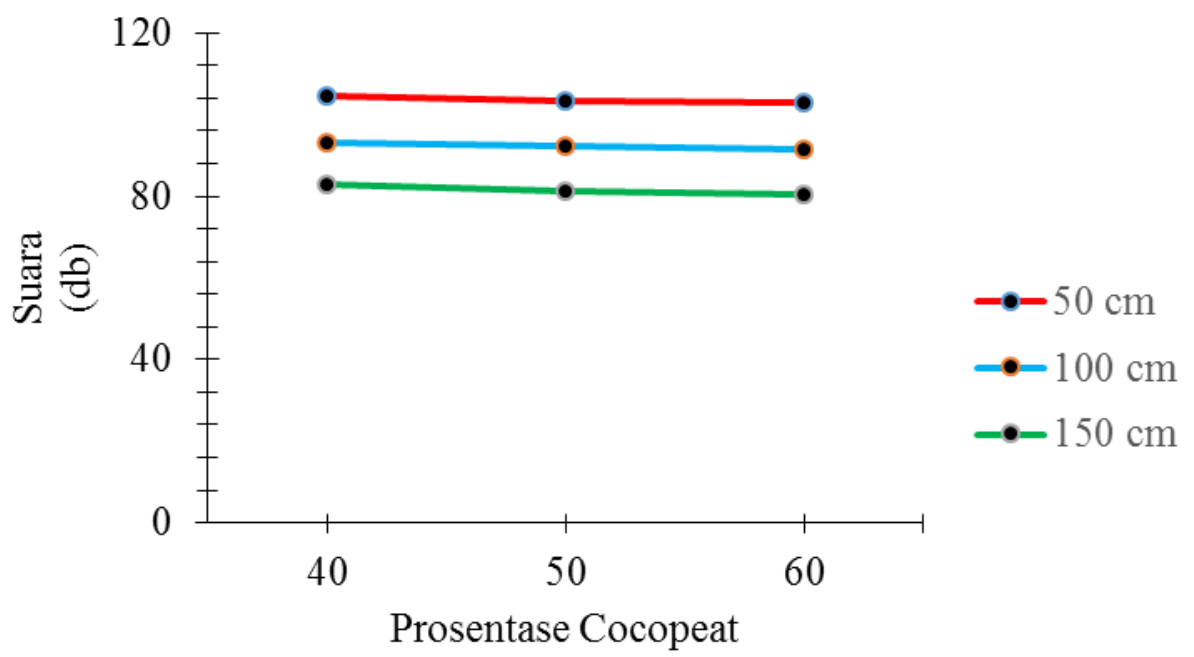

$(\%)$

Figure 5 the results of measurement noise

In Figure 5 above seems a decline trend at each change of mass fraction. With the same distance and different mass fraction seem apparent that a comparison between the powder mass fraction of coconut fibres with a matrix influence the sound attenuation. With coconut fibre powder mass fraction of most has the greatest sound absorption. This is evidenced in the mass fraction of $60 \%-40 \%$, from sound source has a $120 \mathrm{db}$ desibelitas after passing the desibelitas composite dropped to $102.73 \mathrm{db}$. The sound is propagated and passed through the composite, the sound can be absorbed by the composite powder of coconut fibers. This is because the powder coconut fibres have a high absorption and has a hydrophilic nature of the regime. In addition, the powder of coconut fibers have pores - large pore pore pore - so those utilized to accommodate the sound absorption of composite sound so that it will penetrate through the composite has desible low.

While the terms of the distance between the sound source with composite, the composite farther from the source of the voice sound lower desible. This can be proven at a distance of $150 \mathrm{~cm}$, the vote after passing the composite has desible lower. This is because with a composite of the layout away sound source, then allows the sound to propagate all the direction because the sound has the nature of propagation in accordance with the form of a room so after composite sound energy approach the low therefore after passing composite desible low voice.

\section{Adsorption Noise Coeficient}

Table 2 results of calculation of the sound absorbency coefficient

\begin{tabular}{|c|c|c|c|}
\hline \multirow{3}{*}{ Spesimen } & \multicolumn{3}{|c|}{ Jarak spesimen terhadap sumber bunyi } \\
\hline & $50 \mathrm{~cm}$ & $100 \mathrm{~cm}$ & $150 \mathrm{~cm}$ \\
\hline & \multicolumn{3}{|c|}{ Koefisien serap suara $(\alpha)$} \\
\hline $40 \%-60 \%$ (a) & 0,129 & 0,225 & 0,310 \\
\hline $40 \%-60 \%(b)$ & 0,125 & 0,223 & 0,309 \\
\hline $40 \%-60 \%(\mathrm{c})$ & 0,127 & 0,222 & 0,312 \\
\hline Rata - rata & 0,127 & 0,223 & 0,310 \\
\hline $50 \%-50 \%$ (a) & 0,136 & 0,229 & 0,324 \\
\hline $50 \%-50 \%(b)$ & 0,138 & 0,233 & 0,321 \\
\hline $50 \%-50 \%(\mathrm{c})$ & 0,139 & 0,228 & 0,322 \\
\hline Rata - rata & $\mathbf{0 , 1 3 8}$ & $\mathbf{0 , 2 3 0}$ & 0,322 \\
\hline $60 \%-40 \%$ (a) & 0,143 & 0,235 & 0,331 \\
\hline $60 \%-40 \%$ (b) & 0,144 & 0,237 & 0,333 \\
\hline $60 \%-40 \%(\mathrm{c})$ & 0,145 & 0,239 & 0,330 \\
\hline Rata - rata & 0,144 & 0,237 & $\mathbf{0 , 3 3 1}$ \\
\hline
\end{tabular}

From table 2 above, the results of the calculation of the sound absorbency coefficient $(\alpha)$ obtained from the equation:

$$
\alpha=\frac{W_{a}}{W_{i}}
$$


Where: $\alpha=$ coefficient of sound absorbency

Wa = Energy of sound is absorbed $(\mathrm{db})$

$\mathrm{Wi} \quad=$ Energy of sound from the source $(\mathrm{db})$

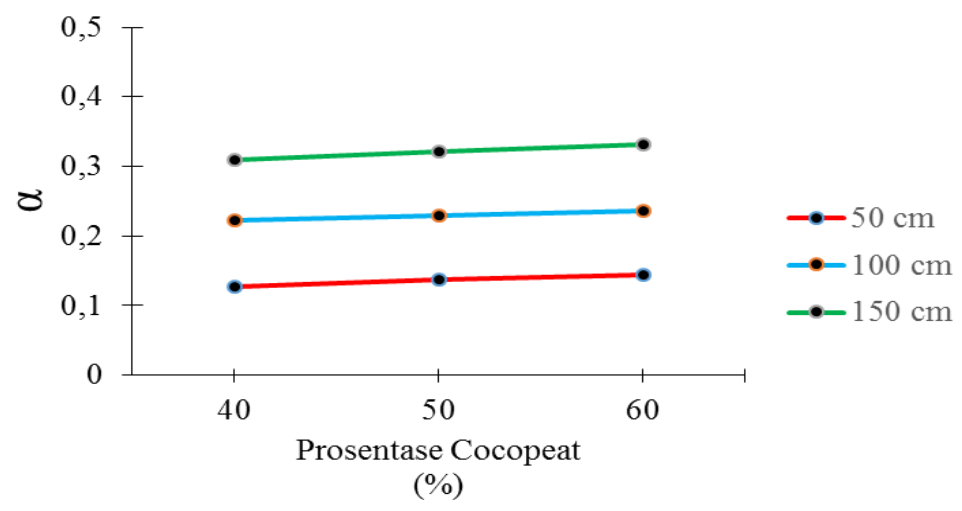

Figure 6 sound absorbency coefficient

Of Figure 6, there is an increasing trend of the sound absorbency coefficient at each change of mass fraction. This is because the sound absorbency coefficient estimates are influenced by great small energy absorbed. In the graphic above, coconut fibers powder mass fraction of $60 \%$ have a high energy absorbed in the calculation of the sound absorbency coefficient has a value that is high.

B. SEM

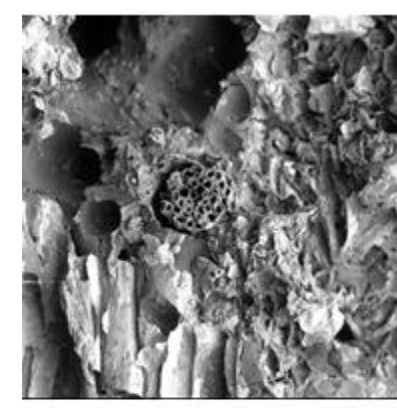

(a) $40 \%$ Cocopeat

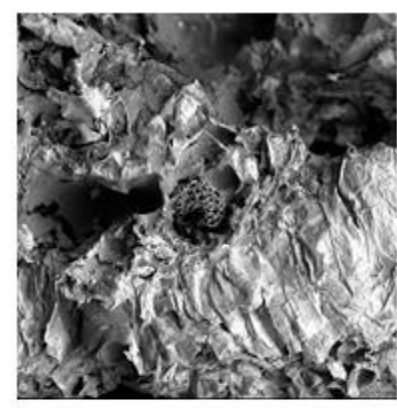

(b) $50 \%$ Cocopeat

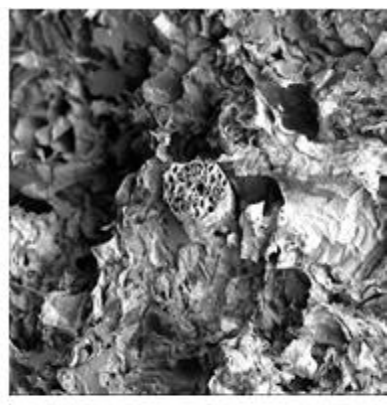

(c) $60 \%$ Cocopeat

Figure 7 SEM Photo composite powder of coconut fibres (cocopeat)

In Figure 7 appears evident is the difference percentage of porosity on the surface of composite powder of coconut fibers. In figure (a) $40 \%$ porosity which shows little cocopeat this is due to the composition of the matrix in composite more than powder coconut fibers. So in a sound absorbing smaller due to the composition of the powder of coconut fibers that have adsorbsi a little. While in picture (c) $60 \%$ percentage porosity cocopeat has more than pictures a and $b$, since the composition of the powder of coconut fibers more than matrix so that the absorbance of sound made by the powder more coconut fibres effective.

\section{CONCLUSION}

This can be taken from the study conclusions as follows: addition of powder coconut fibers can improve sound absorption sound absorption, highs powder mass fraction of coconut fibres with a matrix of $60 \%-40 \%$, this is evidenced on the mass fraction It had the lowest desible after passing composite i.e. $102.73 \mathrm{db}$ with the sound absorbency coefficient 0.144 at a distance of $50 \mathrm{~cm}, 91.57 \mathrm{db}$ with the sound absorbency coefficient 0.237 at a distance of $100 \mathrm{~cm}$ and $80.23 \mathrm{db}$ with a coefficient of 0.331 sound absorbency at a distance of $150 \mathrm{~cm}$, From SEM photo analysis of composite particles obtained powder $60 \%$ coconut fibers have a porosity that much and has the nature of absorption so that the absorbance against the voice of the greater.

\section{REFERENCES}

[1] Muller,D.H., Krobjilowski, A., 2003, New Discovery in the Properties of Composite Reinforced with Natural Fibers, Journal of Industrial Textiles, vol.33, no.2, pp.111-130 Sage Publ.

[2] Arbintarso E. S., 2009, Tinjauan Kekuatan Lengkung Papan Serat Sabut Kelapa Sebagai Bahan Teknik, J. Teknologi, 2, 53-60.

[3] Yohanes,E.,2010, Pengaruh Kombinasi Volume Fraksi Volume Serat Tangkai Kelapa Sawit (Elacis Guineensis) dan Serbuk Tempurung Kelapa Sawit (Elacis Guineensis) Terhadap Sifat Mekanis Komposit Matrik Starch Tepung Garut (Marantha Erundacea)". Seminar Petra.Surabaya

[4] Yohanes, E., 2014,'Desain Komposit Epoksi Berpengisi Serbuk Sabut Kelapa dan Aluminium Untuk Bahan Kampas Rem Dengan Variasi Bentuk Geometri Alur Kampas". Seminar Petra. Surabaya 
[5] Suharyani, 2014, Pemanfaatan Limbah Pelepah Pisang Raja Susu Untuk Bahan Material Dinding Kedap,UMS: Surakarta.

[6] Suwanto, B., 2006, Pengaruh Temperatur Post-Curing terhadap Kekuatan Tarik Komposit Epoksi Resin yang diperkuat Woven Serat Pisang Jurusan Teknik Sipil Politeknik Negeri Semarang, Semarang

[7] Marsyahyo, E., Soekrisno, Rochardjo, H.S.B., Jamasri.,2006, Investigation of Chemical Surface Treatment of Ramie Fiber on Surface Morphology, Tensile Strength and Single Fiber Fracture Modes, International Seminar on Product Design and Development 2006, 13-14 December 2006, Gadjah Mada University, Yogyakarta.

[8] Mohanty, A.K. (2007). Biobased Material for Sustainable Future, Ontario Bioauto Council Annual Seminar, 25 September 2007.

[9] ASTM D629 Qualitative Analysis of Textile Materials

[10] American Society for Testing and Materials ( ASTM ) C-00-2005 ( Standard Pengujian Benda Uji).

[11] ASTMD638,2005, Standard Test Methode for Tensile Properties of Plastics, American Society for Testing Materials, Philadelphia, PA. 